Proceedings

\title{
Synthesis of $\mathrm{NH}_{3}$ on $\mathrm{Fe}, \mathrm{Sm}$ and $\mathrm{Sm}_{2} \mathrm{Fe}_{17}$ surfaces
}

\author{
$\mathrm{Fe}, \mathrm{Sm}, \mathrm{Sm}_{2} \mathrm{Fe}_{17}$ 表面上での $\mathrm{NH}_{3}$ 合成
}

\author{
Tatsuhide Inoue, Kin'ichi Ishikawa, Toshihiro Suzuki and Hirohisa Uchida \\ Department of Applied Physics, Faculty of Engineering, Tokai University \\ 1117 Kitakaname, Hiratsuka, Kanagawa, 259-12 JAPAN \\ ( Accepted for publication 17 November 1994 )
}

1.緒言

近年、 $\mathrm{S} \mathrm{m}_{2} \mathrm{~F} \mathrm{e}_{17} \mathrm{~N}_{\mathrm{X}}$ は、新しい磁石材料として ${ }^{1}$ 注目さ れている。この磁石は、 $\mathrm{S} \mathrm{m}_{2} \mathrm{Fe}_{17}$ 合金に窒素ガスを吸収 させることにより作製される。この $\mathrm{S} \mathrm{m}_{2} \mathrm{Fe}_{17}$ 合金は窒素 ガスとの反応において、窒素濃度 $[\mathrm{N}] /\left[\mathrm{S} \mathrm{m}_{2} \mathrm{~F} \mathrm{e}_{17}\right]$ $\leqq 3$ の範囲で、窒素ガスを吸収させることができる。しかし、 $\mathrm{S} \mathrm{m}_{2} \mathrm{Fe}_{17}$ 合金に、水素ガスを吸放出させた後、窒素ガス を吸収させる、あるいは $\mathrm{S} \mathrm{m}_{2} \mathrm{Fe}_{17}$ 合金と $\mathrm{NH}_{3}$ ガスを反 応させると $[\mathrm{N}] /\left[\mathrm{S} \mathrm{m}_{2} \mathrm{Fe}_{17}\right]>3$ の窒素ガスを吸収 させることができる ${ }^{2}$ 。従って繰り返し水素ガスを吸放出さ せた後、窒素ガスを反応させると、表面で $\mathrm{NH}_{3}$ の合成反応 が起こっているのではないかとが考えられる。そこで、今回 の実験は $\mathrm{Fe} 、 \mathrm{~S} \mathrm{~m} 、 \mathrm{~S} \mathrm{~m}_{2} \mathrm{~F} \mathrm{e}{ }_{17}$ の 3 種類の薄膜に、 $298 \mathrm{~K}$ で、水素ガス、窒素ガスを繰り返し反応させて、 $\mathrm{NH}_{3}$ 合成の確認測定を目的とした。

\section{2. 実験方法}

測定は、反応させるガスを、リザーバーからキャピラリー 管を通して反忘管に導入させ、その時のリザーバーと反応管 の圧力、またキャピラリー管のコンダクタンスよりWagener 法を用いて反応確率及び反応量を求めた。装置全体を脱気し、 イオンゲージ、試料の脱ガスを行い超高真空状態にした。ま た、 $\mathrm{F} \mathrm{e} 、 \mathrm{Sm} 、 \mathrm{~S} \mathrm{~m}_{2} \mathrm{~F} \mathrm{e}_{17}$ 薄膜は $\mathrm{F}$ e ワイヤー、 $\mathrm{S} \mathrm{mブ}$ ロックと熱することにより蒸着させた。実験は、各サンプル フィルムに水素、窒素の順で繰り返しガスをさらした。 $\mathrm{S} \mathrm{m}_{2} \mathrm{Fe}_{17}$ 薄膜は、A E S で測定した結果、 $\mathrm{S} \mathrm{m}_{2} \mathrm{Fe}_{17}$ を構成していた。また、XRDで測定した結果全ての薄膜は、 アモルファス構造をしていた。 $\mathrm{NH}_{3}$ は、四重極型質量分析 計により確認することができる。また、試料を付けずにゲー ジの影響を調べた結果 $\mathrm{NH}_{3}$ 合成は確認されなかった。

\section{3 . 結果}

3. $1 \mathrm{Fe}-\mathrm{H}_{2} \mathrm{H} / \mathrm{Fe}-\mathrm{N}_{2} \quad \mathrm{~N} / \mathrm{H} / \mathrm{Fe}-\mathrm{H}_{2}$ 系

$\mathrm{F}$ e 薄膜と水素ガスを反応量 $\mathrm{N}=15 \times 10^{15}$ $\mathrm{mol}$ e c u l e s / $\mathrm{c} \mathrm{m}^{2}$ まで反応させた後、窒素ガスと 反応させると反応確率は急激に落ちた。このとき $10^{-6} \mathrm{~Pa}$ より高い分圧での、 $\mathrm{NH}_{3}$ 合成は確認されなかった。さらに、 水素ガスと反応させると反応性は初めの水素ガスとの反忘に 比べ低かった。ここでは $4 \times 10^{-5} \mathrm{~Pa}$ a $\mathrm{NH}_{3}$ 分圧が確認 された。
3. $2 \mathrm{~S} \mathrm{~m}-\mathrm{H}_{2} \mathrm{H} / \mathrm{S} \mathrm{m}-\mathrm{N}_{2} \mathrm{~N} / \mathrm{H} / \mathrm{S} \mathrm{m}-\mathrm{H}_{2}$ 系 $\mathrm{S} \mathrm{m}$ 薄膜と水素ガスとの反応において、反応確率 $\mathrm{r}=2 \times 10^{-2}$ でプラトーが見られた。ここでは $\mathrm{S} \mathrm{m} \mathrm{H}$ の水素化物が形成されていると考えられる。水素ガスを

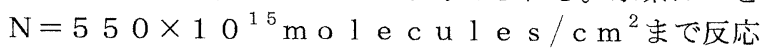
させた後、䇪素ガスと反応させると反応性は初期において 反忘確率 $\mathrm{r}=2 \times 10^{-3}$ 加ら急激に落ちた。この時 $1 \times 10^{-5} \mathrm{P}$ a $の \mathrm{NH}_{3}$ 分圧が確認された。もう一度水素 ガスと反応させると反応性は初めの水素ガスとの反応に比 べ低くかった。この時 $3 \times 10^{-5} \mathrm{~Pa} の \mathrm{NH}_{3}$ 分圧が確認 された。

3. $3 \mathrm{Sm}_{2} \mathrm{Fe}_{17}-\mathrm{H}_{2} \mathrm{H} / \mathrm{Sm}_{2} \mathrm{Fe}_{17}-\mathrm{N}_{2}$ 系 $\mathrm{S} \mathrm{m}{ }_{2} \mathrm{~F} \mathrm{e}{ }_{17}$ 合金薄膜と水素ガスを反応量 $\mathrm{N}=20 \times 10^{15} \mathrm{molecules} / \mathrm{cm}^{2}$ まで反応 させた後、窒素ガスと反応させると反応確率は $\mathrm{r}=3 \times 10^{-2}$ を示した。この時 $9 \times 10^{-5} \mathrm{~Pa}$ の $\mathrm{NH}_{3}$ 分圧が確認された。

\section{4. 結論}

$\mathrm{F}$ e 表面に水素ガス、窒素ガスを反応させた後再び水素 ガスを反応させると $\mathrm{NH}_{3}$ 合成反応が見られた。また $\mathrm{S} \mathrm{m}$ 水素化物表面では窒素の解離が起こり $\mathrm{NH}_{3}$ 合成反応が見 られた。これらのことより $\mathrm{S}$ m、 $\mathrm{F}$ e が $\mathrm{S} \mathrm{m}_{2} \mathrm{~F} \mathrm{e}{ }_{17}$ 合金 表面上で、偏析している場合、水素ガスと窒素ガスを繰り 返し反忘させることにより表面で $\mathrm{NH}_{3}$ 合成が起こり得る。 またアモルファス構造をした $\mathrm{S} \mathrm{m}_{2} \mathrm{~F} \mathrm{e}_{17}$ 合金表面上でも 水素ガスを反応させた後、窒素ガスを反応させると $\mathrm{NH}_{3}$ 合成が確認された。 $\mathrm{S} \mathrm{m}_{2} \mathrm{~F} \mathrm{e}{ }_{17}$ 合金表面上で $\mathrm{NH}_{3}$ が合 成され、 $\mathrm{NH}_{3}$ による窒素の吸収が優先的であるなら、 $\mathrm{S} \mathrm{m}_{2} \mathrm{Fe}_{17}$ 合金は、窒素濃度 $[\mathrm{N}] /\left[\mathrm{S} \mathrm{m}_{2} \mathrm{Fe} \mathrm{e}_{17}\right]$ $=3$ を越える窒素の量を吸収することができる。

5. 参考文献

1 J.M.D.Coey,et al, J.Magn.Mat.,Vol.87,pp.L251-L254.1990

${ }^{2}$ H.H.Uchida,et al,Proc.7th Int.Symp.on mag.Anisotropy \& Coercivity in RE-TM Alloys,Jul.1992,Canberra,Hi-Perm Lab.,Res.Center for Advanced Mineral and materials processing, The Univ. of West Australia,nedlands, 1992,p. 342

'94 SAS Intelligent Symposium 